\title{
A CLINICOEPIDEMIOLOGICAL STUDY OF CUTANEOUS MANIFESTATIONS IN GERIATRIC AGE GROUP
}

\author{
Thakur Rajeev Singh ${ }^{1}$, Shikha Singh ${ }^{2}$
}

${ }^{1}$ Associate Professor, Department of (Dermatology, Venereology, Leprosy), Gandhi Medical College. 2Junior Resident, Department of (Dermatology, Venereology, Leprosy), Gandhi Medical College.

\section{ABSTRACT}

\section{BACKGROUND}

Ageing is a complex process that is due to accumulation of molecular damage overtime. Ageing skin is susceptible to dermatological disorders due to structural and physiological changes that occur as a result of intrinsic or extrinsic ageing. The present study was undertaken to describe the frequency and clinical pattern of cutaneous manifestations in elderly population.

\section{MATERIALS AND METHODS}

This descriptive study was carried on elderly, aged above 60 years. A total of 200 patients were included in the study.

\section{RESULTS}

In this descriptive study, wrinkling of skin was the most common finding followed by xerosis among skin changes associated with ageing. Among pathological skin changes, eczematous skin condition was the most common. Among infections, fungal infections was the most common followed by bacterial and viral. Among papulosquamous disorders psoriasis was the most common and among tumours cherry angioma was the most common.

\section{CONCLUSION}

With ageing, there are so many cutaneous changes that it becomes difficult to delineate physiological from pathological changes. Intrinsic physiological changes in epidermis, dermis vasculature and skin appendages by themselves cause most of the changes.

\section{KEYWORDS}

Ageing, Intrinsic, Extrinsic, Cutaneous Changes.

HOW TO CITE THIS ARTICLE: Singh TR, Singh S. A clinicoepidemiological study of cutaneous manifestations in geriatric age group. J. Evolution Med. Dent. Sci. 2017;6(68):4831-4841, DOI: 10.14260/Jemds/2017/1049

\section{BACKGROUND}

Geriatrics is a Greek Word where gerus means 'old age' and iatrike means medical treatment. It is a branch of medicine concerned with problems of ageing. ${ }^{1}$ Ageing is a complex process that is due to accumulation of molecular damage overtime. $^{2}$

\section{Defining the old}

Ageing is a biological reality which has its own dynamic beyond human control. People aged $60+$ years are generally referred to as older population. ${ }^{3}$ Ageing is progressive, time dependent deterioration of an organism, structural or functional integrity and may be reflected in the ability of the organism to interact with and respond to its environment. Both intrinsic ageing (genetic, chronological ageing) and extrinsic ageing (environmental, photoageing) contribute to cutaneous ageing. ${ }^{4}$ Ageing skin has susceptibility to dermatologic disorders due to the structural and physiological changes that occur as a consequence of intrinsic and extrinsic ageing. 5

Financial or Other, Competing Interest: None.

Submission 15-06-2017, Peer Review 13-08-2017,

Acceptance 19-08-2017, Published 24-08-2017.

Corresponding Author:

Dr. Thakur Rajeev Singh,

\#17-1-391/s/581,

Singareni Colony,

Opposite Vaidehi Ashram

Sayeedabad, Hyderabad-500059,

Telangana.

E-mail: drrajeevsinghthakur@yahoo.co.in

DOI: $10.14260 /$ jemds $/ 2017 / 1049$

\section{(c) (i) $(-)$}

The common skin disorders prevalent in elderly are xerosis, pruritus, dermatoheliosis (photoageing), benign tumours like acrochordons, seborrheic keratosis, cherry angioma, infections like herpes zoster, dermatophytosis, cellulitis, etc.

Eczemas like asteatotic eczema, stasis eczema, discoid eczema and other forms of eczema are common in elderly. ${ }^{4}$ These dermatoses are further complicated by increased frequency of chronic systemic diseases with increasing age.

The improvement in socioeconomic conditions and major advances in medical field have led to significant increase in life expectancy. India being the second largest populated country in the world with 72 million elderly persons above 60 years of age as on 2001 and the number is likely to increase to 179 million in 2031 and further to 301 million in 2051.5 The geriatric population ( $>60$ years) in India was $6.9 \%$ of total population in 2011 (family welfare statistics in India- 2014) and will contribute $12.4 \%$ of total population by 2026 AD. The population is getting older with a greater percentage of population over 60 years. Hence, an increased emphasis on geriatric medicine is inevitable, geriatric dermatology is a specialty which requires special attention. With this background, the present study was undertaken to describe the frequency and clinical pattern of cutaneous manifestations in elderly population. The population aged above 60 years was considered for this study. ${ }^{3}$

\section{MATERIALS AND METHODS}

\section{Source of Data and Number}

- The descriptive study was carried on elderly aged above 60 years attending Dermatology OPD as well as IPD at Mahatma Gandhi Memorial Hospital, Warangal.

- A total of 200 patients were included in the study. 


\section{Inclusion Criteria}

- Patients aged above 60 years were included in the descriptive study.

- Patient willing to give informed consent for taking part in the descriptive study.

\section{Exclusion Criteria}

Onset of certain dermatological diseases genodermatoses which interfere with ageing skin, photosensitive genodermatoses, premature ageing genodermatoses, albinos, inherited disorders of DNA instability were excluded.

\section{Method of Collection of Data}

a) A detailed history in all cases was taken-

- Name, age, sex, occupation, address,

- Chief complaints,

- Past history,

- Treatment and drug history,

- Family history,

- History of any allergy and personal history.

b) Complete general physical examination and systemic examination.

c) Thorough dermatological examination was carried out including the skin all over the body, hair, nails, oral and genital mucosa.

\section{Routine Investigations}

- Haemoglobin, total leukocyte count, differential count.

- RBS.

- Urine routine.

\section{Other Tests}

ESR, liver function tests, blood urea, serum creatinine, lipid profile, serum electrolytes, thyroid profile and stool for occult blood were done when required.

\section{Dermatological Procedures}

- Scrapings and nail clipping for fungal infection,

- $\quad$ Patch test, skin prick test,

- Skin biopsy,

- Pus for culture and sensitivity were done when required.

Procedures followed were in accordance with ethical standards of the responsible committee on human experimentation and with Helsinki declaration of 1975 that was revised in 2000 .

\section{Statistics}

A total of 200 cases with age above 60 years attending OPD and IPD of Mahatma Gandhi Memorial Hospital were included in the study.

\section{Age Distribution}

Maximum number of patients in this descriptive study belongs to age group of 61 - 65 years (32\%) followed by 66 - 70 years (25\%). The eldest patient was of 90 years and the mean age in the study was 70.3 years.

\begin{tabular}{|c|c|c|}
\hline Age Groups & Number of Patients & Percentage (\%) \\
\hline $61-65$ & 64 & $32 \%$ \\
\hline $66-70$ & 50 & $25 \%$ \\
\hline $71-75$ & 46 & $23 \%$ \\
\hline $76-80$ & 28 & $14 \%$ \\
\hline $80+$ & 12 & $6 \%$ \\
\hline Grand Total & 200 & $\mathbf{1 0 0}$ \\
\hline \multicolumn{3}{|c|}{ Table 1. Age Distribution } \\
\hline
\end{tabular}

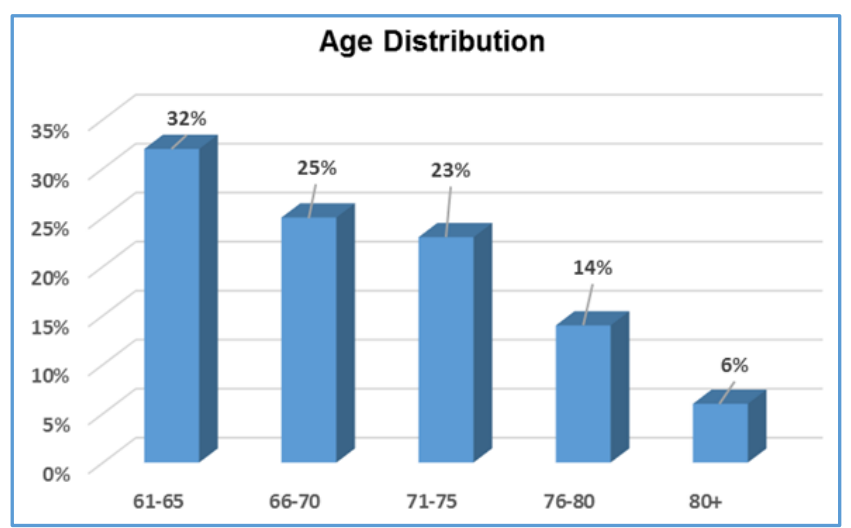

Chart 1. Age Distribution ( $N=200)$

\section{Sex Distribution}

In this descriptive study of the 200 patients, there were 125 males $(62.5 \%)$ and 75 females (37.5\%). Male-to-Female ratio in the study was 1.66: 1.

\begin{tabular}{|c|c|c|}
\hline Sex & Number of Patients & Percentage (\%) \\
\hline Female & 75 & $37.5 \%$ \\
\hline Male & 125 & $62.5 \%$ \\
\hline Grand Total & $\mathbf{2 0 0}$ & $\mathbf{1 0 0}$ \\
\hline \multicolumn{2}{|c|}{ Table 2. Sex Distribution (N= 200) } \\
\hline
\end{tabular}

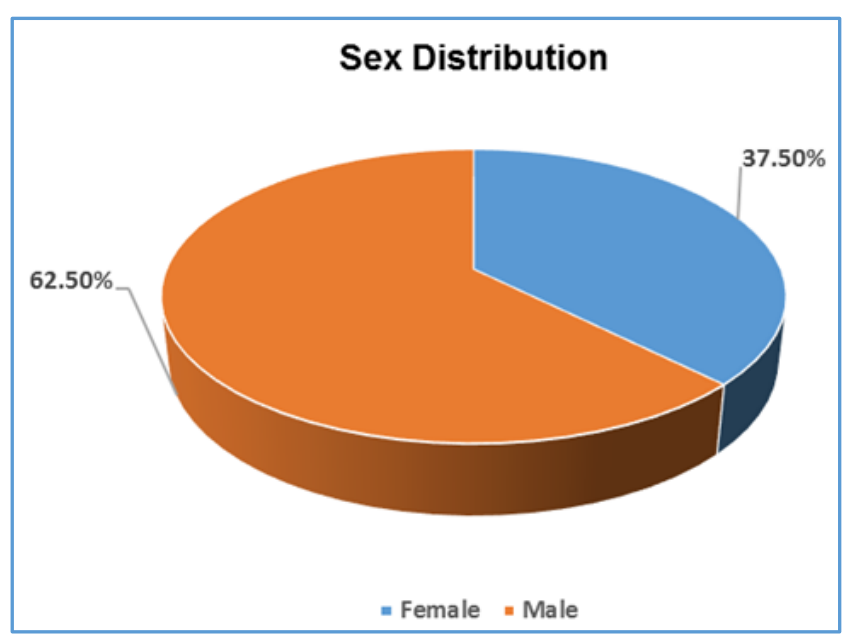

Chart 2. Sex Distribution

\section{Occupation Distribution}

In this descriptive study of the 200 patients 102 were retired (51\%), of which 22 were females and 80 were males; 30 (15\%) were agriculturists, of which 20 were males and 10 were females; 40 females were housewives (20\%); 28 (14\%) patients were doing some business, of which 3 were females and 25 males. Thus, most male patients were retired and most of the female patients were housewives. 


\begin{tabular}{|c|c|c|}
\hline Type & Number of Patients & Percentage (\%) \\
\hline Agricultural & 30 & $15 \%$ \\
\hline Housewives & 40 & $20 \%$ \\
\hline Retired & 102 & $51 \%$ \\
\hline Business & 28 & $14 \%$ \\
\hline \multicolumn{2}{|c|}{ Table 3. Occupation Distribution (N= 200) } \\
\hline
\end{tabular}

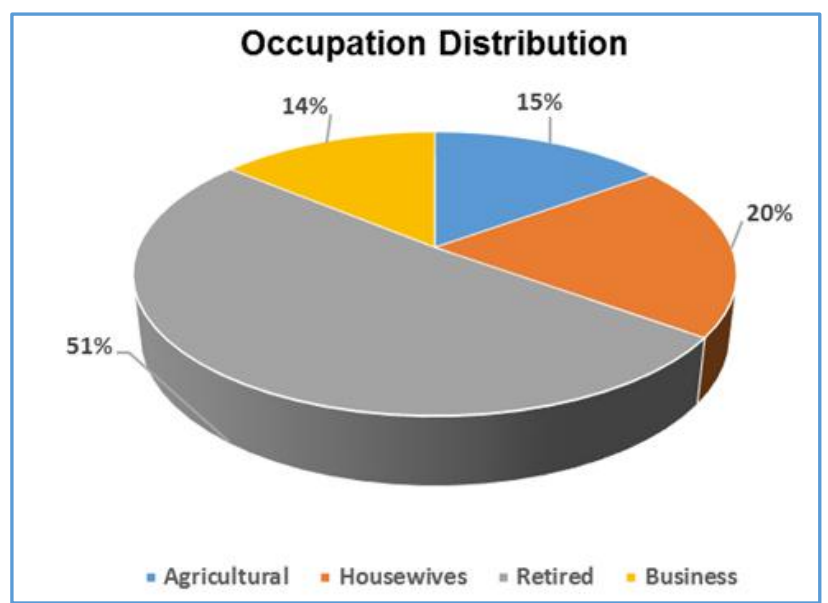

Chart 3. Occupation Distribution

\begin{tabular}{|c|c|c|c|}
\hline Type & Female & Male & Total \\
\hline Agricultural & 10 & 20 & 30 \\
\hline Housewives & 40 & & 40 \\
\hline Retired & 22 & 80 & 102 \\
\hline Business & 3 & 25 & 28 \\
\hline Total & $\mathbf{7 5}$ & $\mathbf{1 2 5}$ & $\mathbf{2 0 0}$ \\
\hline Table 4. Occupation Distribution by Gender $(\boldsymbol{N}=\mathbf{2 0 0})$ \\
\hline
\end{tabular}

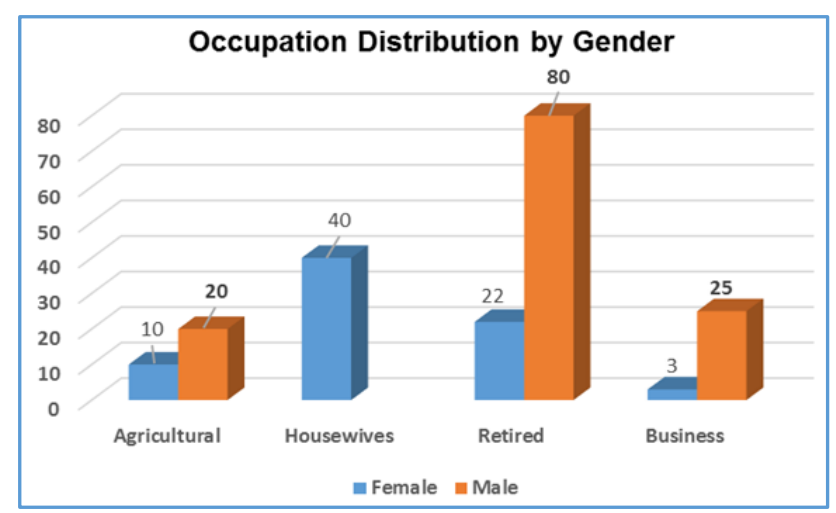

Chart 4. Occupation Distribution by Gender

\section{Associated Diseases}

Diabetes Mellitus was the commonest associated disease seen in 55 cases (27.5\%) followed by Hypertension in 46 cases (23\%), IHD in 8 cases (4\%), Anaemia in 7 cases (3.5\%), Benign Prostatic Hypertrophy in 5 cases (2.5\%), Hypothyroidism in 4 cases (2\%), Bronchial Asthma in 3 cases (1.5\%), Alcoholic Liver Disease in 3 cases (1.5\%), HIV in 1 cases (0.5\%), Kidney Disease in 2 cases (1\%), Rheumatoid Arthritis in 1 case $(0.5 \%)$, Peptic Ulcer in 2 cases (1\%) and COPD (Chronic Obstructive Pulmonary Disease) in 2 cases (1\%).

\begin{tabular}{|c|c|c|}
\hline Associated Diseases & $\begin{array}{c}\text { No. of } \\
\text { Cases }\end{array}$ & $\begin{array}{c}\text { Percentage } \\
\text { (\%) }\end{array}$ \\
\hline Diabetes Mellitus & 55 & $27.5 \%$ \\
\hline Hypertension & 46 & $23 \%$ \\
\hline IHD & 8 & $4 \%$ \\
\hline
\end{tabular}

\begin{tabular}{|c|c|c|}
\hline Anaemia & 7 & $3.5 \%$ \\
\hline Benign Prostatic Hypertrophy & 5 & $2.5 \%$ \\
\hline Hypothyroidism & 4 & $2 \%$ \\
\hline Bronchial Asthma & 3 & $1.5 \%$ \\
\hline Alcoholic Liver Disease & 3 & $1.5 \%$ \\
\hline HIV & 1 & $0.5 \%$ \\
\hline Kidney Disease & 2 & $1 \%$ \\
\hline Rheumatoid Arthritis & 1 & $0.5 \%$ \\
\hline Peptic Ulcer & 2 & $1 \%$ \\
\hline COPD & 2 & $1 \%$ \\
\hline Table 5. Associated Diseases (N= 200) \\
\hline
\end{tabular}

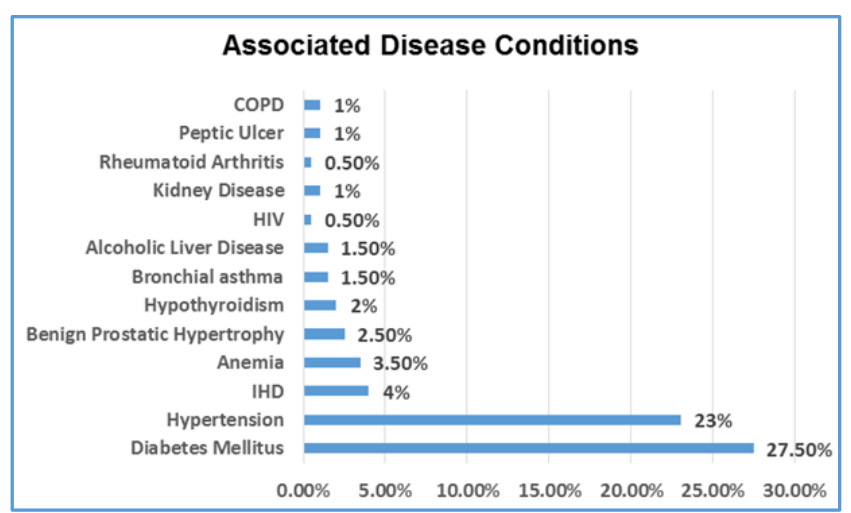

Chart 5. Associated Disease Conditions $(N=200)$

\section{Generalised Pruritus}

Xerosis was associated with generalised pruritus in 44 cases (22\%), Diabetes Mellitus was associated in 16 cases (8\%), Anaemia in 4 cases (2\%), Hypothyroidism in 4 (2\%) cases, Alcoholic Liver Disease in 3 cases (1.5\%), HIV in 1 case $(0.5 \%)$ and Kidney disease in 2 cases (1\%). Thus, generalised pruritus was most commonly associated with xerosis in our study.

\begin{tabular}{|c|c|c|c|}
\hline $\begin{array}{c}\text { Sl. } \\
\text { No. }\end{array}$ & $\begin{array}{c}\text { Conditions Associated } \\
\text { with GP }\end{array}$ & $\begin{array}{c}\text { No. of } \\
\text { Cases }\end{array}$ & $\begin{array}{c}\text { Percentage } \\
\text { (\%) }\end{array}$ \\
\hline 1. & Xerosis & 44 & $22 \%$ \\
\hline 2. & Diabetes Mellitus & 16 & $8 \%$ \\
\hline 3. & Anaemia & 4 & $2 \%$ \\
\hline 4. & Hypothyroidism & 4 & $2 \%$ \\
\hline 5. & Alcoholic Liver Disease & 3 & $1.5 \%$ \\
\hline 6. & Kidney Disease & 2 & $1 \%$ \\
\hline 7. & HIV & 1 & $0.5 \%$ \\
\hline \multicolumn{3}{|c|}{ Table 6. Generalised Pruritus } \\
\hline
\end{tabular}

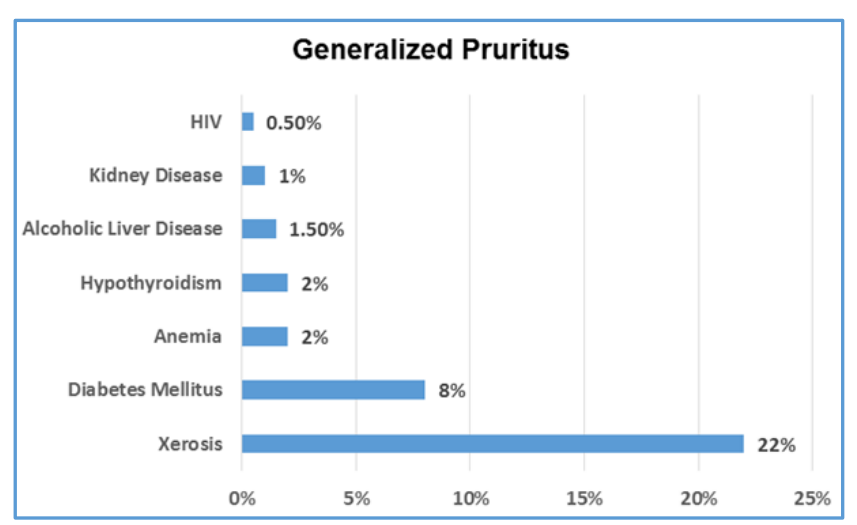

Chart 6. Generalised Pruritus 


\section{Skin Changes with Ageing}

In this descriptive study, wrinkling of the skin was one of the commonest finding and was seen in 182 cases (91\%). Xerosis was seen in 105 cases (52.5\%), IGH was seen in 70 cases (35\%), Senile Lentigines was seen in 34 cases $(17 \%)$ and Senile Comedones in 14 cases (7\%).

\begin{tabular}{|c|c|c|}
\hline Skin Changes & $\begin{array}{c}\text { Number of } \\
\text { Patients }\end{array}$ & $\begin{array}{c}\text { \% of Total } \\
\text { Patients }\end{array}$ \\
\hline Wrinkles & 182 & $91.0 \%$ \\
\hline Xerosis & 105 & $52.5 \%$ \\
\hline IGH & 70 & $35 \%$ \\
\hline Senile Lentigines & 34 & $17 \%$ \\
\hline Senile Comedones & 14 & $7 \%$ \\
\hline \multicolumn{2}{|c|}{ Table 7. Skin Changes with Ageing (N= 200) } \\
\hline
\end{tabular}

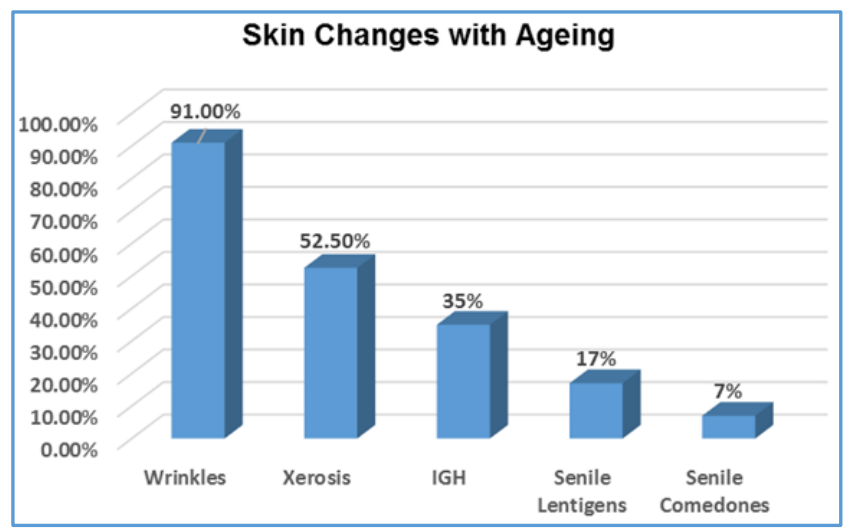

Chart 7. Skin Changes with Ageing

\section{Pathological Skin Changes}

In this descriptive study eczematous conditions were seen in 53 cases $(26.5 \%)$, commonest was exposure dermatitis seen in 10 cases $(5 \%)$ followed by chronic eczema in 8 cases $(4 \%)$, contact dermatitis in 8 cases (4\%), stasis eczema in 9 cases (4.5\%), infectious eczematous dermatitis in 5 cases $(2.5 \%)$, asteatotic eczema in 4 cases (2\%), $2(1 \%)$ cases each of seborrheic dermatitis, nummular eczema in 2 cases $(1 \%)$ hand eczema in 3 cases (1.5\%), 1 case each of follicular eczema and foot eczema was seen.

\begin{tabular}{|c|c|c|}
\hline $\begin{array}{c}\text { Type of Eczematous } \\
\text { Conditions }\end{array}$ & $\begin{array}{c}\text { No. of } \\
\text { Cases }\end{array}$ & $\begin{array}{c}\text { Percentage } \\
\text { (\%) }\end{array}$ \\
\hline Exposure Dermatitis & 10 & $5 \%$ \\
\hline Chronic Eczema & 8 & $4 \%$ \\
\hline Contact Dermatitis & 8 & $4 \%$ \\
\hline Stasis Eczema & 9 & $4.5 \%$ \\
\hline $\begin{array}{c}\text { Infectious Eczematous } \\
\text { Dermatitis }\end{array}$ & 5 & $2.5 \%$ \\
\hline Asteatotic Eczema & 4 & $2 \%$ \\
\hline Seborrheic Dermatitis & 2 & $1 \%$ \\
\hline Nummular Eczema & 2 & $1 \%$ \\
\hline Hand Eczema & 3 & $1.5 \%$ \\
\hline Follicular Eczema & 1 & $0.5 \%$ \\
\hline Foot Eczema & 1 & $0.5 \%$ \\
\hline Grand Total & $\mathbf{5 3}$ & $\mathbf{2 6 . 5 \%}$ \\
\hline Table 8. Eczematous Conditions (N= 200) \\
\hline
\end{tabular}

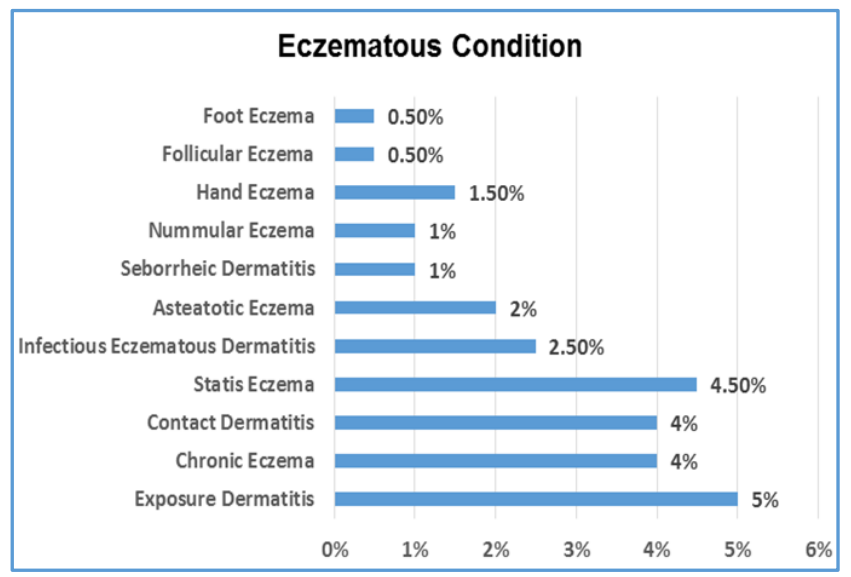

Chart 8. Eczematous Condition

\section{Types of Infections}

In this descriptive study infections were seen in 67 cases (33.5\%), of which fungal infections was seen in 32 cases (16\%), bacterial infections was seen in 18 cases (9\%) and viral infections in 17 cases (8.5\%). No infestations were seen.

Of the 32 cases of fungal infections, dermatophytosis was seen in 25 cases $(12.5 \%)$ and candidiasis in 7 cases $(3.5 \%)$. Among the bacterial infections cellulitis was seen in 8 cases (4\%), leprosy in 4 cases (2\%), furuncle in 3 cases $(1.5 \%)$ folliculitis in 2 cases $(1 \%)$ and 1 case $(0.5 \%)$ of scrofuloderma was seen. Among viral infections, Herpes zoster was seen in 15 cases $(7.5 \%)$ and viral warts in 2 cases $(1 \%)$.

\begin{tabular}{|c|c|c|c|}
\hline $\begin{array}{c}\text { Type of } \\
\text { Infections }\end{array}$ & Subtype & $\begin{array}{l}\text { No. of } \\
\text { Cases }\end{array}$ & $\begin{array}{c}\text { Percentage } \\
\text { (\%) }\end{array}$ \\
\hline \multirow{3}{*}{$\begin{array}{c}\text { Fungal } \\
\text { Infections }\end{array}$} & Fungal & Total 32 & $16 \%$ \\
\hline & Dermatophytosis & 25 & $12.5 \%$ \\
\hline & Candidiasis & 7 & $3.5 \%$ \\
\hline \multirow{6}{*}{$\begin{array}{l}\text { Bacterial } \\
\text { Infections }\end{array}$} & Bacterial & Total 18 & $9 \%$ \\
\hline & Cellulitis & 8 & $4.0 \%$ \\
\hline & Leprosy & 4 & $2 \%$ \\
\hline & Furuncle & 3 & $1.5 \%$ \\
\hline & Folliculitis & 2 & $1 \%$ \\
\hline & Scrofuloderma & 1 & $0.5 \%$ \\
\hline \multirow{4}{*}{$\begin{array}{c}\text { Viral } \\
\text { Infections }\end{array}$} & Viral & Total 17 & $8.5 \%$ \\
\hline & Herpes Zoster & 15 & $7.5 \%$ \\
\hline & Viral Warts & 2 & $1 \%$ \\
\hline & Grand Total & 67 & $33.5 \%$ \\
\hline \multicolumn{4}{|c|}{ Table 9. Types of Infection } \\
\hline
\end{tabular}

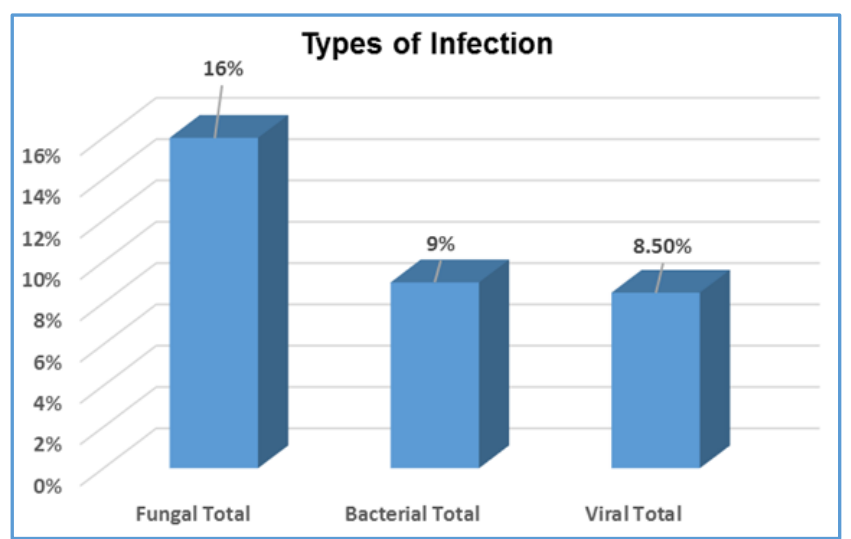

Chart 9. Types of Infection $(N=200)$ 


\section{Papulosquamous Disorders}

In this descriptive study Psoriasis was seen in 10 cases (5\%), Lichen planus in 4 cases $(2 \%)$ and 1 case $(0.5 \%)$ of Pityriasis rubra pilaris was seen.

\begin{tabular}{|c|c|c|}
\hline Types & No. of Cases & Percentage (\%) \\
\hline Psoriasis & 10 & $5 \%$ \\
\hline Lichen Planus & 4 & $2 \%$ \\
\hline Pityriasis Rubra Pilaris & 1 & $0.5 \%$ \\
\hline Grand Total & $\mathbf{1 5}$ & $\mathbf{7 . 5} \%$ \\
\hline Table 10. Papulosquamous Disorders (N= 200) \\
\hline
\end{tabular}

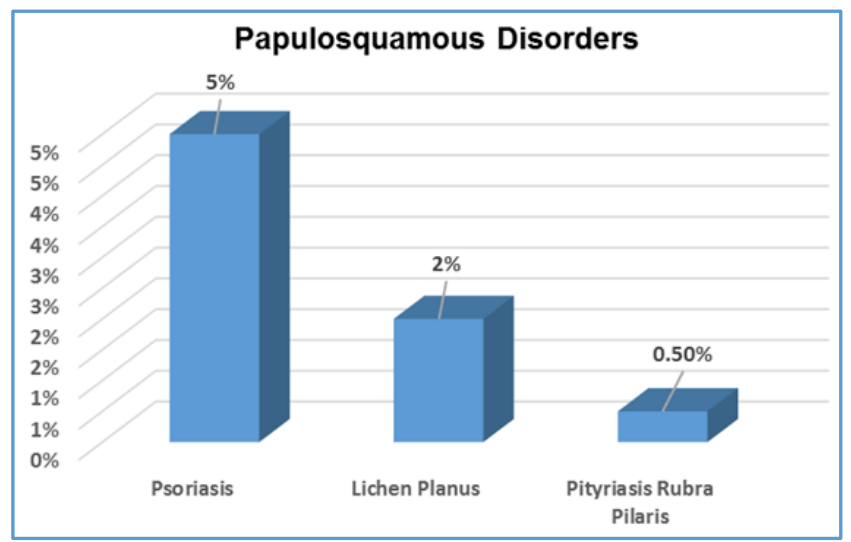

Chart 10. Papulosquamous Disorders

\section{Benign Tumours of Skin}

The most common benign skin tumour seen was Cherry angiomas $(102,51 \%)$ followed by seborrheic keratosis in 84 cases (42\%), Dermatosis papulosa nigra in 67 cases $(33.5 \%)$, acrochordons in $53(26.5 \%)$ cases, 1 case $(0.5 \%)$ of Sebaceous cyst and 2 cases (1\%) of Syringoma.

\begin{tabular}{|c|c|c|c|}
\hline $\begin{array}{c}\text { Sl. } \\
\text { No. }\end{array}$ & Condition & $\begin{array}{c}\text { No. of } \\
\text { Cases }\end{array}$ & $\begin{array}{c}\text { Percentage } \\
\text { (\%) }\end{array}$ \\
\hline 1. & Cherry Angiomas & 102 & $51 \%$ \\
\hline 2. & Seborrheic Keratosis & 84 & $42 \%$ \\
\hline 3. & $\begin{array}{c}\text { Dermatosis Papulosa } \\
\text { Nigra }\end{array}$ & 67 & $33.5 \%$ \\
\hline 4. & Acrochordons & 53 & $26.5 \%$ \\
\hline 5. & Sebaceous Cysts & 1 & $0.5 \%$ \\
\hline 6. & Syringoma & 2 & $1 \%$ \\
\hline \multicolumn{3}{|c|}{ Table 11. Benign Tumours of Skin } \\
\hline
\end{tabular}

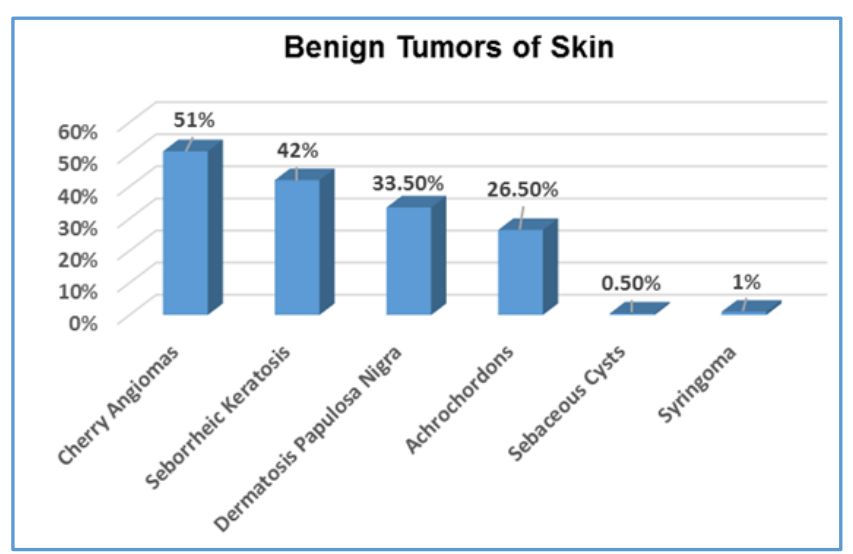

Chart 11. Benign Tumours of Skin
Premalignant and Malignant Tumours

In this descriptive study, one case of premalignant tumours which was seen was Bowen's disease. Among the malignant conditions, 2 cases of basal cell carcinoma and 1 case of squamous cell carcinoma was seen.

\begin{tabular}{|c|c|c|c|}
\hline Types & Subtype & $\begin{array}{c}\text { No. of } \\
\text { Cases }\end{array}$ & $\begin{array}{c}\text { Percentage } \\
\text { (\%) }\end{array}$ \\
\hline $\begin{array}{c}\text { Pre-Malignant } \\
\text { Condition }\end{array}$ & Bowen's & 1 & $0.5 \%$ \\
\hline \multirow{2}{*}{$\begin{array}{c}\text { Malignant } \\
\text { Tumours }\end{array}$} & Basal Cell Carcinoma & 2 & $1 \%$ \\
\cline { 2 - 4 } & $\begin{array}{c}\text { Squamous Cell } \\
\text { Carcinoma }\end{array}$ & 1 & $0.5 \%$ \\
\hline Grand Total & \multicolumn{4}{|c|}{$\mathbf{4}$} & $\mathbf{2 \%}$ \\
\hline \multicolumn{2}{|r|}{ Table 12. Premalignant and Malignant Tumours } \\
\hline
\end{tabular}

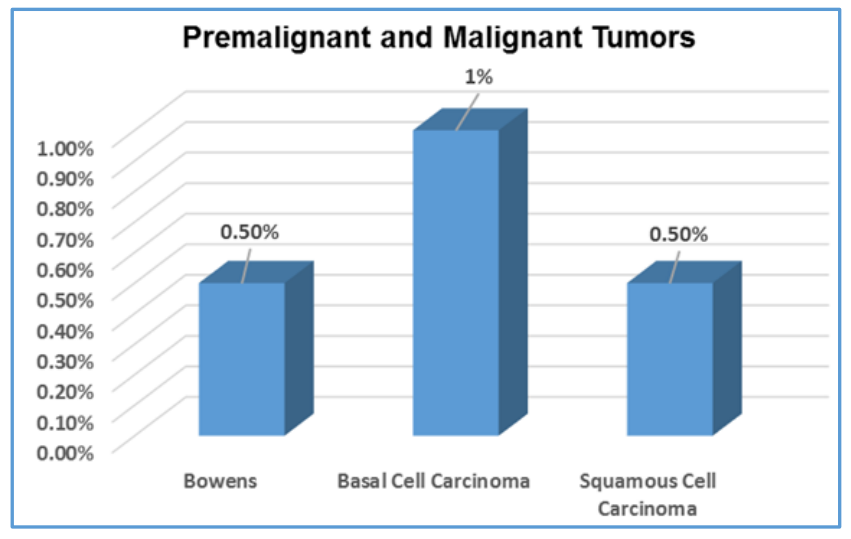

Chart 12. Premalignant and Malignant Tumours $(N=200)$

\section{Bullous Disorders}

In this descriptive study 7 cases of bullous disorders was seen, out of which 4 cases (2\%) had Bullous Pemphigoid, 3 cases (1.5\%) had Pemphigus Vulgaris.

\begin{tabular}{|c|c|c|}
\hline Types & No. of Cases & Percentage (\%) \\
\hline Bullous Pemphigoid & 4 & $2.0 \%$ \\
\hline Pemphigus Vulgaris & 3 & $1.5 \%$ \\
\hline Grand Total & $\mathbf{7}$ & $3.5 \%$ \\
\hline \multicolumn{2}{|c|}{ Table 13. Bullous Disorders } \\
\hline
\end{tabular}

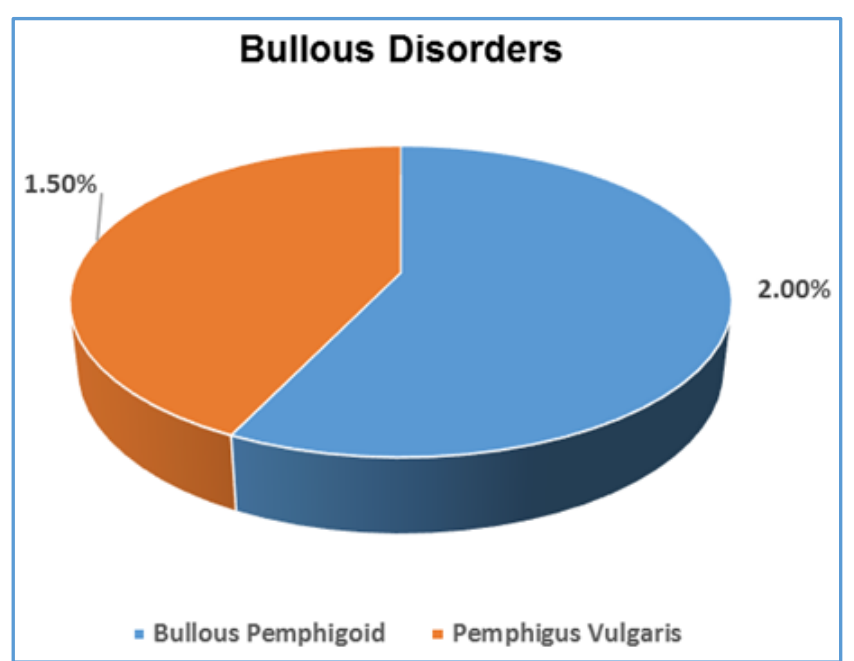

Chart 13. Bullous Disorders (N=200) 


\section{Psychocutaneous Disorders}

In this descriptive study 13 cases of Psychocutaneous disorders was seen, of which 10 (5\%) cases had Lichen simplex chronicus and 3 (1.5\%) cases had Prurigo nodularis.

\begin{tabular}{|c|c|c|}
\hline Types & No. of Cases & Percentage (\%) \\
\hline Lichen simplex chronicus & 10 & $5 \%$ \\
\hline Prurigo nodularis & 3 & $1.5 \%$ \\
\hline Grand Total & $\mathbf{1 3}$ & $\mathbf{6 . 5 \%}$ \\
\hline \multicolumn{2}{|c|}{ Table 14. Psychocutaneous Disorders } \\
\hline
\end{tabular}

\section{Vascular Disorders}

In this descriptive study, 3 cases $(1.5 \%)$ had senile purpura and $2(1 \%)$ cases of pigmented purpuric dermatoses was seen

\begin{tabular}{|c|c|c|c|}
\hline $\begin{array}{c}\text { Sl. } \\
\text { No. }\end{array}$ & Condition & $\begin{array}{c}\text { No. of } \\
\text { Cases }\end{array}$ & $\begin{array}{c}\text { Percentage } \\
\text { (\%) }\end{array}$ \\
\hline 1. & Senile purpura & 3 & $1.5 \%$ \\
\hline 2. & $\begin{array}{c}\text { Pigmented purpuric } \\
\text { dermatosis }\end{array}$ & 2 & $1 \%$ \\
\hline \multicolumn{3}{|c|}{ Table 15. Vascular Disorders } \\
\hline
\end{tabular}

\section{Drug Reactions in Elderly}

In this descriptive study out of the 200 cases, 4 cases had drug reactions, 2 cases had Lichenoid drug eruptions and 2 cases of drug reaction to Ciprofloxacin.

\section{Miscellaneous Conditions}

In this descriptive study, Chronic Urticaria was seen in 4 cases (2\%). Colloid milia in 3 cases (1.5\%); 2 (1\%) cases each of Lichen amyloidosis and Lichen sclerosus et atrophicus was seen; $1(0.5 \%)$ each case of Parapsoriasis, Favre-Racouchot Syndrome, Pruritus ani, Pyogenic Granuloma, Lupus Profundus were seen, 2 (1\%) cases each of reactive perforating collagenosis and granuloma annulare and 3 $(1.5 \%)$ cases of polymorphous light eruptions.

\begin{tabular}{|c|c|c|c|}
\hline $\begin{array}{c}\text { Sl. } \\
\text { No. }\end{array}$ & Condition & $\begin{array}{c}\text { No. of } \\
\text { Cases }\end{array}$ & $\begin{array}{c}\text { Percentage } \\
\text { (\%) }\end{array}$ \\
\hline 1. & Chronic Urticaria & 4 & $2 \%$ \\
\hline 2. & Colloid Milia & 3 & $1.5 \%$ \\
\hline 3. & Lichen Amyloidosis & 2 & $1 \%$ \\
\hline 4. & Lichen sclerosus et atrophicus & 2 & $1 \%$ \\
\hline 5. & Parapsoriasis & 1 & $0.5 \%$ \\
\hline 6. & Reactive perforating & 2 & $1 \%$ \\
\hline 7. & collagenosis & 2 & $1 \%$ \\
\hline 8. & Favre-Ranuloma annulare & 1 & $0.5 \%$ \\
\hline 9. & Polymorphous light eruptions & 3 & $1.5 \%$ \\
\hline 10. & Pruritus ani & 1 & $0.5 \%$ \\
\hline 11. & Pyogenic granuloma & 1 & $0.5 \%$ \\
\hline 12. & Lupus profundus & 1 & $0.5 \%$ \\
\hline \multicolumn{3}{|c|}{ Table 16. Miscellaneous Conditions } \\
\hline \multicolumn{3}{|c|}{} \\
\hline
\end{tabular}

\section{Nail Changes in Elderly}

In this descriptive study, among the nail changes loss of lustre was the commonest followed by vertical ridging in 97 cases (48.5\%), Onychorrhexis in 64 cases (32\%), Onychomycosis in 22 cases $(11 \%)$, Thickening in 33 cases $(16.5 \%)$, Thinning in 14 cases (7\%), Subungual Hyperkeratosis in 12 cases (6\%), Platyonychia in 6 cases (3\%), Koilonychia in 10 cases (5\%), Beau's lines in 4 cases (2\%) and Pitting in 4 cases (2\%).

\begin{tabular}{|c|c|c|c|}
\hline $\begin{array}{c}\text { Sl. } \\
\text { No. }\end{array}$ & Condition & $\begin{array}{c}\text { No. of } \\
\text { Cases }\end{array}$ & $\begin{array}{c}\text { Percentage } \\
\text { (\%) }\end{array}$ \\
\hline 1. & Loss of Lustre & 102 & $51 \%$ \\
\hline 2. & Vertical Ridging & 97 & $48.5 \%$ \\
\hline 3. & Onychorrhexis & 64 & $32 \%$ \\
\hline 4. & Thickening & 33 & $16.5 \%$ \\
\hline 5. & Onychomycosis & 22 & $11 \%$ \\
\hline 6. & Thinning & 14 & $7 \%$ \\
\hline 7. & Subungual & 12 & $6 \%$ \\
\hline 8. & Hyperkeratosis & 10 & $5 \%$ \\
\hline 9. & Koilonychias & 6 & $3 \%$ \\
\hline 10. & Platyonychia & 4 & $2 \%$ \\
\hline 11. & Beau's Lines & 4 & $2 \%$ \\
\hline \multicolumn{4}{|c|}{ Pitting } \\
\hline
\end{tabular}

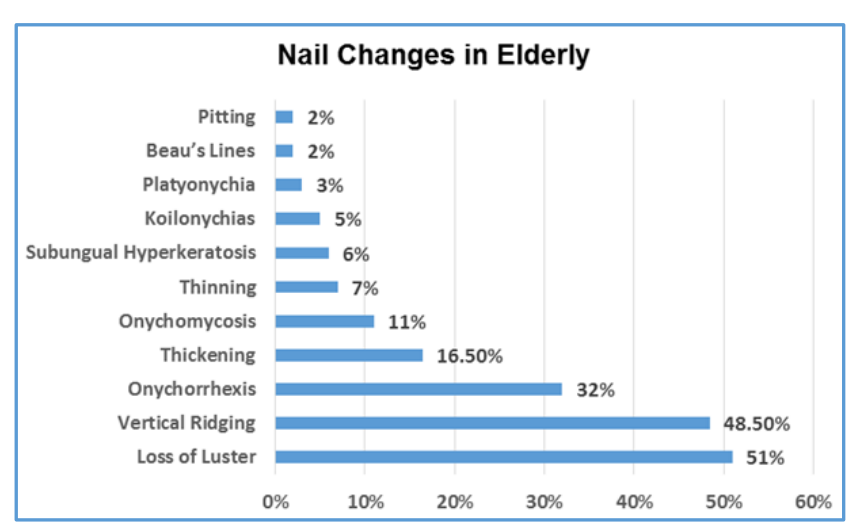

Chart 14. Nail Changes in Elderly $(N=200)$

\section{Hair Changes in Elderly}

In this descriptive study, greying of hair was one of the most common and was seen in 150 cases (75\%). Out of 75 female patients diffuse hair loss was seen in 45 females and out of 125 males 84 cases had Androgenic alopecia.

\begin{tabular}{|c|c|c|c|c|}
\hline $\begin{array}{c}\text { Sl. } \\
\text { No. }\end{array}$ & Condition & $\begin{array}{c}\text { No. of } \\
\text { Cases }\end{array}$ & $\begin{array}{c}\text { Males/ } \\
\text { Females }\end{array}$ & $\begin{array}{c}\text { Percentage } \\
\text { (\%) }\end{array}$ \\
\hline 1. & $\begin{array}{c}\text { Diffuse Hair Loss in } \\
\text { Females }\end{array}$ & 45 & 75 & $60 \%$ \\
\hline 2. & $\begin{array}{c}\text { Androgenic } \\
\text { Alopecia in Males }\end{array}$ & 84 & 125 & $67.2 \%$ \\
\hline \multicolumn{4}{|c|}{ Table 18. Hair Changes in Elderly } \\
\hline
\end{tabular}

\section{DISCUSSION}

Ageing is a complex process that is due to accumulation of molecular damage overtime. ${ }^{2}$ Both intrinsic ageing (genetic, chronological ageing) and extrinsic ageing (environmental, photoageing) contribute to cutaneous ageing. ${ }^{4}$ Ageing skin has susceptibility to dermatologic disorders due to the structural and physiological changes that occur as a consequence of intrinsic and extrinsic ageing. ${ }^{5}$

\section{Number of Cases in Relation to Age and Sex}

In our descriptive study, a total of 200 patients varying in age from 61 - 93 years were examined. Of these, 125 patients (62.5\%) were males and 75 (37.5\%) were females. The eldest patient was 90 years of age. Mean age was 70.3 years. 
In a study by Sukhum Jiamton, Charrusri Leeyaphan, Nundita Prasertoworoun, Viboon Omcharsen, out of 516 patients range from 60 - 94, 217 (47\%) were males and 299 (57.9\%) were females. ${ }^{6}$ In a study by Talukdar K and Mitra D, out of 360 patients (60 and above) 257 (71.4\%) were male patients and 103 (28.6\%) were female patients. ${ }^{7}$ In a study by Raveendra L, in 200 patients 65 years and above, 147 (71\%) were males and 58 (29\%) were females. ${ }^{8}$ In a study by Rashmi Jindal et al out of 1380 patients aged 60 years and above 921 $(66.7 \%)$ were males and $459(33.3 \%)$ were females. ${ }^{9}$

In a study by Sheetal MP and Shashikumar BM, out of 300 patients aged 60 and above $204(68 \%)$ were males and 96 (32\%) were females. ${ }^{10}$

Droller made a study on random cases of 476 individuals. Out of this, 192 were men and 284 were women. All patients were between 60 and 90 years of age. ${ }^{11}$ Tindall and Smith ${ }^{12}$ studied 163 volunteers, all above 64 years of age. Verbov ${ }^{13}$ examined 170 consecutive patients aged 60 to 90 years in an OPD. Weismann et al ${ }^{14}$ studied 494 residents of a Danish home for the aged between 55 and 106 years of age. Beauregard and Gilchrest ${ }^{15}$ studied 68 patients aged between 50 - 91 years. Patange and Fernandez ${ }^{16}$ studied 200 cases in an ODP setting, aged 55 - 85 years of age, of which $63 \%$ were males and $37 \%$ were females. Priya Cinna and Thappa did a hospital-based descriptive study on 500 elderly, females aged 50 years and above and males aged 60 years and above. ${ }^{17}$ In their study, female-to-male ratio was 1.34: 1 . Out of 500,213 were males $(42.6 \%)$ and 287 (57.4) were females.

Our descriptive study is comparable to Rashmi Jindal and Sheetal MP.

\section{Associated Conditions}

In this descriptive study, 94 patients (47\%) had associated systemic illnesses. Some patients had more than one systemic illness. Diabetes mellitus was the commonest association seen in 55 cases $(27.5 \%)$ followed by hypertension $(23 \%)$.

In a study by Shashikant B Dhumale and Rajesh Khyalappa, diabetes mellitus was the common association in $27.5 \%$ and hypertension in $15 \% .18$ In a study by Priya Cinna and Thappa, Diabetes (28.9\%) and Hypertension $25.5 \%)$ were the commonest associated condition, ${ }^{17}$ which is similar to our study. Beauregard and Gilchrest ${ }^{15}$ described $89.7 \%$ of patients to have major medical illnesses, of which $88.2 \%$ were on medication. Patange and Fernandez observed associated systemic ailments in $30 \%$ of cases. ${ }^{16}$

Our study is comparable to Shashikant B Dhumale and Rajesh Khyalappa with reference to diabetes mellitus.

\section{Symptomatology}

In our descriptive study, generalised pruritus was seen in 60 cases $(30 \%)$, of which xerosis was associated with generalised pruritus in 44 cases $(22 \%)$ associated with Diabetes Mellitus in 16 cases (8\%), Anaemia in 4 cases (2\%), Hypothyroidism in 4 (2\%) cases, Alcoholic Liver Disease in 3 cases (1.5\%), 1 (0.5\%) case of HIV and $2(1 \%)$ cases of Kidney disease. Thus, generalised pruritus was most commonly associated with xerosis in our study.

In a study by Sheetal MP and Shashikumar BM, pruritus was seen in $32 \% .^{10}$ In a study by Shashikant B Dhumale and Rajesh Khyalappan, pruritus was seen in 20.5\%.18 Droller noticed generalised pruritus in $29.7 \%$ males and $29.2 \%$ females. ${ }^{11}$ Priya Cinna and Thappa found in $49.6 \%$, of whom 29.8\% were associated with Xerosis. ${ }^{17}$ Beauregard and Gilchrest ${ }^{15}$ found in $29 \%$ patients. Patange and Fernandez ${ }^{16}$ observed pruritus in $78.5 \%$ patients.

Findings of generalised pruritus of our study were similar to that seen by Beauregard and Gilchrest and Sheetal MP and Shashikumar BM.

\section{Skin Changes with Ageing}

With ageing, there are so many cutaneous changes that it becomes difficult to delineate physiological from the pathological. Intrinsic physiologic changes in the epidermis, dermis, vasculature and skin appendages by themselves cause most of the changes.

\section{a) Wrinkling}

This was a common finding in the study and noticed in 182 patients [91\%].

In a study by Sheetal MP and Shashikumar BM, wrinkling was seen in $89 \% .^{10}$ In a study by Raveendra L, wrinkling was seen in $88 \%{ }^{8}$

In study by Grover and Narasimhalu, wrinkling was seen in 191 (95.5\%). ${ }^{19}$ Priya Cinna and Thappa found in 100\%,17 Tindall and Smith ${ }^{12}$ [94\%] and Beauregard and Gilchrest in 95.6\%. Patange and Fernandez do not mention the incidence of wrinkling. ${ }^{16}$ Our descriptive study is comparable to Grover and Narasimhalu.

\section{b) Xerosis}

Xerosis literally means dry skin. When associated with eczematous changes, it is called asteatotic eczema. In our study, Xerosis was seen in 105 patients [52.5\%]. Tindall and Smith ${ }^{12}$ reported an incidence of xerosis in $77 \%$, while Beauregard and Gilchrest ${ }^{15}$ found it in $85 \%$ of patients. Chopra et al found in 108 (50.8\%) cases. ${ }^{20}$ Our study shows similar results as that seen in Chopra et al, but lower incidence of xerosis in this study as compared to those by Tindall and Smith and Beauregard and Gilchrest could be attributed to the tropical climate in which the patients of this study live and relative humidity in tropical climates is more than that in temperate climates reducing the degree of xerosis.

\section{c) Senile Lentigines}

Senile lentigines in this study was found in 34 cases [17\%]. In a study by Raveendra L, senile lentigines was seen in $30(15 \%) .{ }^{8}$ Sheetal MP and Shashikumar BM seen in $30.3 \% .^{10}$ Talukdar $\mathrm{K}$ and Mitra D seen in $10.8 \% .80$ Tindall Smith ${ }^{12}$ reported senile lentigines in 51\%. Beauregard and Gilchrest ${ }^{15}$ reported senile lentigines in 70.6\%. Patange and Fernandez ${ }^{16}$ found an incidence of $12 \%$. The incidence of senile lentigines in this study was comparable to that of Patange and Fernandez, and Raveendra L.

\section{d) Idiopathic Guttate Hypomelanosis}

Idiopathic guttate hypomelanosis in our study was seen in 35\% (70 cases). In a study by Priya Cinna and Thappa $26 \%(130),{ }^{17}$ Beauregard and Gilchrest ${ }^{15}$ reported an incidence of $24.4 \%$ and Patange and Fernandez found it in $24.5 \%$ (49). In study by Talukdar K and Mitra D it was 
seen in 22.5\%; in a study by Sheetal MP and Shashikumar BM it seen in $45.3 \%$ and Raveendra $\mathrm{L}$ saw it in $33 \%$. Our descriptive study is comparable to Raveendra $\mathrm{L}$.

\section{e) Senile Comedones}

Dermatoheliosis is a combination of skin changes produced by solar damage and consists of senile comedones, irregular pigmentation, wrinkling, scaling actinic keratosis, elastosis and malignancy. Senile comedones commonly represent solar damage and in this study they represent dermatoheliosis. An incidence of 14 cases [7\%] of senile comedones (represented by dermatoheliosis) was found in this study.

In study by Raveendra L, senile comedones were present in 28\%. ${ }^{8}$ Sheetal MP and Shashikumar BM found it in $31.3 \%$ and Shashikant B Dhumale found it in 13\%.

In a study by Grover and Narasimhalu ${ }^{19}$ it was found in 13 (6.5\%); in a study by Priya Cinna and Thappa they observed it in $23(4.6 \%)$ individuals. ${ }^{17}$ Patange and Fernandez ${ }^{16}$ have reported an incidence of $11.5 \%$.

Our descriptive study is comparable to Grover and Narasimhalu.

\section{Pathological Skin Changes}

Among the various pathologic skin changes seen in the elderly in this study, the following conditions are discussed:- Papulosquamous disorders, eczematous conditions, infections and infestations, benign skin tumours, premalignant and malignant skin tumours, vascular disorders, bullous disorders, psychocutaneous disorders, drug reactions and miscellaneous skin changes.

a) Papulosquamous Disorders

In this descriptive study, psoriasis was seen in 10 cases (5\%). In a study by Raveendra $\mathrm{L}^{8}$ psoriasis was found in 7\%; Sukhum Jiamton et al ${ }^{6}$ found it in $8.3 \%$; Talukdar $\mathrm{K}^{7}$ and Mitra D found it in $4.2 \%$; Jindal et al ${ }^{9}$ found it in $5.4 \%$. Tindall and Smith found psoriasis in $1 \%$ of cases. Beauregard and Gilchrest ${ }^{15}$ mention an incidence of $2.9 \%$, while Patange and Fernandez ${ }^{16}$ found it in $10.5 \%$. This study compares well with that of Jindal et al.

In our descriptive study, 4 cases [2\%] of lichen planus was seen. In a study by Raveendra $\mathrm{L},{ }^{8}$ Lichen planus was found in 10 cases (5\%); Talukdar $\mathrm{K}^{7}$ and Mitra D found it in 3.6\%; Jindal et $\mathrm{al}^{9}$ found it in $3.3 \%$.

One case of Pityriasis rubra pilaris was seen in [0.5\%].

\section{b) Eczematous Conditions}

In our descriptive study, eczema was found in 53 cases (26.5\%). Contact dermatitis was found in 8 cases (4\%), exposure dermatitis in 10 cases (5\%), stasis eczema in 9 cases $(4.5 \%)$, seborrheic dermatitis in 2 cases (1\%), Asteatotic eczema in 4 cases (2\%) and infective eczematous dermatitis in 5 cases $(2.5 \%)$.

In a study by Jindal et al, ${ }^{9}$ Seborrheic dermatitis was found in $20(1.4 \%)$, contact dermatitis in $101(7.3 \%)$ and Stasis dermatitis in $8(0.6 \%) .{ }^{9}$ In a study by Talukdar $\mathrm{K}^{7}$ and Mitra D Eczema was found in 34\%, Seborrheic dermatitis in 16 cases (4.4\%), Stasis eczema in 15 (4.2\%), Contact dermatitis in 14 $(3.9 \%)$ and Asteatotic eczema in 8 (2.2\%). In a study by Sukhum Jiamton et al, ${ }^{6}$ Eczematous dermatitis was found in
$31.2 \%$ (161), Asteatotic eczema in $10.3 \%$, Seborrheic dermatitis in $2.9 \%$, Contact dermatitis in $1.7 \%$ and Stasis eczema in $0.6 \%$. In a study by Shashikant Dhumale and Rajesh Khyalappa, ${ }^{18}$ Stasis eczema was found in $19 \%$. In a study by Raveendra L, ${ }^{8}$ Eczematous dermatitis was found in $31 \%$.

Priya Cinna and Thappa ${ }^{17}$ found an incidence of eczema in $24.2 \%$ (121) similar to that seen in our study. Verbov ${ }^{13}$ reported an incidence of $24.7 \%$ with $10 \%$ having allergic contact dermatitis. Weismann ${ }^{14}$ reported seborrheic dermatitis in $7 \%$, stasis dermatitis in $6.9 \%$ and contact dermatitis in 3.8\%. Johnson ${ }^{21}$ reported seborrheic dermatitis in $3.6 \%$, contact dermatitis in $2 \%$ and eczema in $1.8 \%$. Beauregard and Gilchrest ${ }^{15}$ reported contact dermatitis in $11.8 \%$, seborrheic dermatitis in $10.5 \%$ and stasis dermatitis in $5.9 \%$. Patange and Fernandez ${ }^{16}$ found contact dermatitis in $7.5 \%$ and lichen simplex chronicus in $12 \%$.

Incidence of Seborrheic dermatitis compares well with Jindal et al. The incidence of contact dermatitis compares well with that of Weismann. And incidence of stasis eczema was similar to that of Beauregard and Gilchrest. Incidence of contact dermatitis and stasis dermatitis compares well with Talukdar and Mitra.

\section{c) Infective Conditions and Infestations}

In this descriptive study infective conditions was seen in $67(33.5 \%)$ cases, fungal infections was seen in $32(16 \%)$ cases, viral infections in $17(8.5 \%)$ cases and bacterial infections in 18 (9\%).

Dermatophytosis was seen in 25 cases (12.5\%), Candidal infections in 7 cases (3.5\%). Among bacterial infections 4 cases of Leprosy, 3 cases of furuncle, 2 cases of Bacterial folliculitis and 8 cases of cellulitis was seen. Among viral infections 15 (7.5\%) cases of Herpes Zoster, of which 7 had post-herpetic neuralgia and $2(1 \%)$ cases of viral warts were seen.

In a study by Jindal et al fungal infections were found in 247 (18\%), viral in 105 (7.6\%), bacterial 37 (2.7\%). ${ }^{9}$ By Talukdar $\mathrm{K}$ and Mitra D fungal infections were found in 61 (16.9\%), bacterial in $32(8.9 \%)$ and viral in $28(7.8 \%) .^{7}$ By Raveendra $\mathrm{L}$, fungal infections were found in $11 \%$ and viral in $8 \%{ }^{8}$

Tindall and Smith ${ }^{12}$ reported dermatophytosis in $79 \%$, but not the incidence of other infections. Johnson reported an incidence of $12.7 \%$ for dermatophytosis. Beauregard and Gilchrest $^{15}$ found dermatophytosis in $17.7 \%$. Patange and Fernandez reported infective dermatoses as $34.5 \%$ of the total dermatoses. Out of this fungal infection was found in $17.5 \%$, bacterial infection in $8.5 \%$ and viral infections in $5 \%$. Priya Cinna and Thappa ${ }^{17}$ found infectious conditions in $46.8 \%$, of which fungal infections were the commonest (34.4\%), onychomycosis in $22.2 \%$, bacterial infections in $0.8 \%$ and viral infections in $0.6 \%$.

The incidence of infective conditions in our study compares well with that of Talukdar, Mitra and Patange Fernandez. Incidence of viral infections compares well with Raveendra L.

\section{d) Benign Tumours of the Skin}

In our descriptive study, seborrheic keratosis was seen in $84(42 \%)$ cases. Cherry angiomas were seen in 102 (51\%) cases, Dermatosis papulosa nigra was seen in 67 cases (33.5\%) and Acrochordons was seen in 53 cases (26.5\%). 
In a study by Raveendra L, ${ }^{8}$ Seborrheic keratosis was found in $56 \%$, dermatosis papulosa nigra was found in $47 \%$, Cherry angiomas in 37\% and Acrochordons in 19.5\%. By Shashikant B Dhumale and Rajesh Khyalappa,18 Seborrheic keratosis was found in $15 \%$. In a study by Talukdar K and Mitra $\mathrm{D}^{7}$ Cherry angiomas was found in 210 (58.3\%), Seborrheic keratosis in $84(23.3 \%)$ and Skin tags in 74 (20.6\%). Priya Cinna and Thappa ${ }^{17}$ found Seborrheic keratosis in $253(50.6 \%)$ cases and Cherry angioma in 36 (7.2\%) cases and Acrochordons in $49 \%$. Grover and Narasimhalu ${ }^{20}$ found Seborrheic keratosis in $43 \%$ and Cherry angioma in $63 \%$.

Tindall and Smith found Seborrheic keratosis in $88 \%$ of cases and Cherry angiomas in $75 \%$ of cases. Beauregard and Gilchrest ${ }^{15}$ observed seborrheic keratosis in $61.2 \%$ and cherry angiomas in 53.7 cases. They also reported $58.8 \%$ incidence of Dermatosis papulosa nigra. Patange found Cherry angioma in $46.5 \%$, Seborrheic keratosis in $37.5 \%$ and acrochordons in $24.5 \%$ of cases.

The findings in this study are comparable with that of Beauregard and Gilchrest for cherry angioma. Finding of Seborrheic keratosis in this study compares well with that of Grover and Narasimhalu. Findings in our study is comparable to Mitra D and Talukdar K, and Patange for acrochordons.

\section{e) Premalignant and Malignant Tumours}

One case of Bowen's disease were seen in the descriptive study; 3 (1.5\%) malignant tumours were encountered in our study, of which 1 was Squamous cell carcinoma and 2 were Basal cell carcinoma.

In a study by Jindal et $\mathrm{al}^{9}$ precancerous conditions were present in $0.4 \%$ and cutaneous malignancies in $0.8 \%$. Out of 1,380 patients more than 60 years basal cell carcinoma was found in 7 patients and squamous cell carcinoma in 1 case. In a study by Talukdar K and Mitra D,7 squamous cell carcinoma was found in 3 cases $(0.8 \%)$ and basal cell carcinoma in 2 cases $(0.6 \%)$. In a study by Shashikant Dhumale and Rajesh Khyalappa, ${ }^{18}$ out of 200 patients basal cell carcinoma was found in 3 cases and squamous cell carcinoma in 2 cases.

Priya Cinna and Thappa ${ }^{17}$ reported 5 cases of malignancy (1\%). Patange has reported no case of skin malignancy. The lower incidence of premalignant and malignant skin tumours in this study could be because of the lower incidence of skin cancer in racially pigmented skin, which was found in our study population. Higher incidence was seen by Verbov, ${ }^{13}$ who found an incidence of $13.5 \%$ for malignant skin tumours. Beauregard and Gilchrest have reported actinic keratoses in $17.7 \%$ and skin cancer in $4.4 \%$.

\section{f) Vascular Disorders}

In this descriptive study, senile purpura was seen in 3 cases $(1.5 \%)$ and pigmented purpuric dermatoses in 2 cases $(1 \%)$.

In a study by Raveendra L, senile purpura was found in 14 cases $(7 \%)$. In a study by Shashikant Dhumale, senile purpura was found in 61 cases (30.5\%). Tindall and Smith have reported pigmented purpuric dermatoses in 31\% of cases. Beauregard and Gilchrest ${ }^{15}$ observed senile purpura in $11.9 \%$, while Patange and Fernandez ${ }^{16}$ found an incidence of $9 \%$ of senile purpura. Thus, occurrence of senile purpura and pigmented purpuric dermatoses in the present study is much lower than that observed by others. The lower incidence of purpuric dermatoses and purpura in this study could be due to the difficulty in spotting purpuric changes in the racially pigmented skin of our study population.

\section{g) Bullous Disorders}

Among the various bullous disorders, only 4 cases of bullous pemphigoid (2\%) and 3 cases of pemphigus vulgaris $(1.5 \%)$ was seen.

In a study by Raveendra $\mathrm{L}^{8}$ Bullous pemphigoid was found in 3 patients (1.5\%). In a study by Talukdar K and Mitra $\mathrm{D},{ }^{7}$ Bullous pemphigoid was found in 8 patients $(2.2 \%)$ and Pemphigus vulgaris in 2 cases $(0.6 \%)$. Priya Cinna and Thappa ${ }^{17}$ found Pemphigus vulgaris in 9 cases $(1.8 \%)$ and Bullous pemphigoid in 8 cases (1.6\%). Findings were similar to Talukdar K and Mitra D for Bullous pemphigoid and with Priya Cinna and Thappa for Pemphigus vulgaris.

\section{h) Psychocutaneous Dermatoses}

In our descriptive study, $13(6.5 \%)$ cases of psychocutaneous dermatoses was observed. Of which 10 (5\%) cases had Lichen simplex chronicus and 3 (1.5\%) cases had prurigo nodularis.

In a study by Jindal et al, Lichen simplex chronicus was found in 26 cases (1.9\%). In a study by Talukdar K and Mitra D Prurigo nodularis was found in $2.8 \%$ and Lichen simplex chronicus in $8.6 \%$. Our study is comparable to Talukdar $\mathrm{K}$ and Mitra D.

\section{i) Miscellaneous Skin Conditions}

In this descriptive study, Chronic Urticaria was seen in 4 cases (2\%), Colloid milia in 3 cases $(1.5 \%), 1$ case $(0.5 \%)$ of Parapsoriasis, 2 cases each of Lichen amyloidosis and Lichen sclerosus et atrophicus was seen. One case (0.5\%) of Favre-Racouchot syndrome, 2 cases each of Reactive perforating collagenosis and Granuloma annulare, 3 cases of polymorphous light eruption, 1 case each of Pruritus ani, Pyogenic granuloma and Lupus profundus were seen. In a study by Talukdar K and Mitra D urticaria was found in $4.7 \%$ and in a study by Jindal et al it was found in $3 \%$.

\section{Hair Changes}

Greying of hair was almost universal and seen in 150 cases $(75 \%)$. Hair loss in elderly women in our study was mostly diffuse thinning of hair and was seen in $60 \%$ and androgenic alopecia in males was noticed in (67.2\%).

In a study by Priya Cinna and Thappa, ${ }^{17}$ greying was seen in $97.2 \%$ males and $90.9 \%$ females. Diffuse hair thinning was seen in $67.24 \%$ males and androgenic alopecia was seen in $55.39 \%$ males. Patange ${ }^{16}$ observed male pattern baldness in 20 males and diffuse hair loss in 94 females in their study of 200 patients.

\section{Nail Changes}

In our descriptive study loss of lustre was the commonest finding and was seen in 102 cases (51\%), vertical ridging was seen in 97 cases (48.5\%) and was the second common nail change and onychomycosis was seen in 22 cases $(11 \%)$. 
In a study by Raveendra L vertical ridging was found in $47 \%$, loss of lustre in $44 \%$ and onychomycosis in $7 \%$. Priya Cinna and Thappa ${ }^{17}$ found that loss of lustre was the commonest nail change seen in $50.8 \%$, vertical ridging was seen in $24 \%$ and onychomycosis in $22.5 \%$. Patange and Fernandez observed loss of lustre in $20.5 \%$. Grover and Narasimhalu ${ }^{19}$ observed loss of lustre in $64 \%$, vertical ridging in $72.5 \%$ and onychomycosis in $12 \%$.

The findings of loss of lustre of nails compares well with that of Priya Cinna and Thappa. Finding of onychomycosis compares well with Grover and Narasimhalu. Findings of vertical ridging compares well with Raveendra L.

- 53 cases (26.5\%), commonest was exposure dermatitis seen in 10 cases (5\%).

- In this descriptive study infections were seen in 67 cases (33.5\%), of which fungal infections was seen in 32 cases (16\%), bacterial infections was seen in 18 cases $(9 \%)$ and viral infections in 17 cases (8.5\%). No infestations were seen. Of the 32 cases of fungal infections, Dermatophytosis was seen in 25 cases (12.5\%) and Candidiasis in 7 cases (3.5\%). Among the bacterial infections, Cellulitis was seen in 8 cases (4\%), Leprosy in 4 cases (2\%), Furuncle in 3 cases (1.5\%), Folliculitis in 2 cases $(1 \%)$ and 1 case $(0.5 \%)$ of Scrofuloderma was seen. Among viral infections, Herpes zoster was seen in 15 cases $(7.5 \%)$ and viral warts in 2 cases (1\%).

- In this descriptive study Psoriasis was seen in 10 cases (5\%), Lichen planus in 4 cases $(2 \%)$ and 1 case $(0.5 \%)$ of Pityriasis rubra pilaris was seen.

- $\quad$ The most common benign skin tumour seen was Cherry angiomas 102 (51\%) followed by Seborrheic keratosis in 84 cases $(42 \%)$, Dermatosis papulosa nigra in 67 cases (33.5\%), acrochordons in 53 (26.5\%) cases, 1 case (0.5\%) each of sebaceous cyst and syringoma.

- In this descriptive study 1 case of premalignant tumours were seen, which was Bowen's disease. Among the malignant condition, 2 cases of basal cell carcinoma and 1 case of squamous cell carcinoma was seen.

- In this descriptive study 7 cases of bullous disorders was seen, out of which 4 cases (2\%) had Bullous pemphigoid, 3 cases (1.5\%) had Pemphigus vulgaris.

- In this study 13 cases of Psychocutaneous disorders was seen, of which 10 (5\%) cases had Lichen simplex chronicus and $3(1.5 \%)$ cases had Prurigo nodularis.

- In this descriptive study, 3 cases (1.5\%) had senile purpura and $2(1 \%)$ cases of pigmented purpuric dermatoses was seen.

- 4 cases of drug reactions were seen, of which 2 had lichenoid drug eruption and 2 had drug reaction to ciprofloxacin.

- In this descriptive study, Chronic urticaria was seen in 4 cases (2\%); 3 (1.5\%) cases of Colloid milia, 1 case $(0.5 \%)$ of Parapsoriasis, 2 cases each of Lichen amyloidosis and Lichen sclerosus et atrophicus were seen; 1 case $(0.5 \%)$ each of Favre-Racouchot syndrome, 2 cases each of Reactive perforating collagenosis and Granuloma annulare, 3 cases of Polymorphous light eruption, 1 case each of Pruritus ani, Pyogenic granuloma and Lupus profundus were seen.
- Among the nail changes, loss of lustre was the commonest followed by vertical ridging in 102 cases (51\%).

- In this descriptive study, greying of hair was one of the most common and was seen in 150 cases (75\%). Out of 75 female patients diffuse hair loss was seen in 45 females (60\%) and out of 125 males 84 (67.2\%) cases had Androgenic alopecia.

\section{CONCLUSION}

- In our study, the commonest age group was 61 - 65 years.

- Majority of patients were males in this study.

- Majority of male patients were retired and majority of female patients were housewives.

- Diabetes mellitus was the commonest associated systemic disease.

- Generalised pruritus was most commonly associated with xerosis.

- Wrinkling was one of the commonest skin changes seen. Xerosis, senile lentigines, senile comedones and IGH were the other senile skin changes.

- Various pathological skin diseases like eczemas, infections, benign tumours, malignant tumours, Papulosquamous diseases, psychocutaneous diseases, vascular conditions, bullous disorders and drug reactions were seen.

- Loss of lustre was the commonest nail change seen.

- Greying of hair was very commonly seen.

\section{REFERENCES}

[1] Masoro EJ. Ageing: current concepts in ageing. In: Masoro EJ. Oxford, England: Oxford University Press 1995: p. 3.

[2] Millington GWM, Graham-Brown RAC. Skin and skin diseases throughout life. In: Burns T, Breathnach S, Cox $\mathrm{N}$, eds. Rook's Textbook of dermatology. $8^{\text {th }}$ edn. Oxford: Wiley Blackwell Publication 2010;8:21-9.

[3] World Health Organization. Definition of elderly person.

www.who.int/healthinfo/survey/ageingdefinitionolde r/en/index.html 1.09.2013.

[4] Fenske NA, Lober CW. Ageing and its effects on skin. In: Moschella SL, Hurley HJ. eds. Dermatology $3^{\text {rd }}$ edn. Philadelphia: WB Saunders 1992:107-22.

[5] Rajan SI, Sarma PS, Mishra US. Demography of Indian aging, 2001- 2051. J Aging Soc Policy 2003;15(2-3):1130.

[6] Leeyaphan, Charussri. Skin diseases among elderly attending out-patient dermatologic clinic, Siriraj hospital. Siriraj Medical Journal 2014:66(6).

[7] Talukdar K, Mitra D. A cross sectional observational study to evaluate various cutaneous manifestations in geriatic age group. Int J Med Res \& Rev 2016;4(2):18692.

[8] Raveendra L. A clinical study of geriatric dermatoses. Our Dermatol Online 2014;5(3):235-9.

[9] Jindal R, Jain A, Roy S, et al. Skin disorders among geriatric population at a tertiary care center in Uttarakhand. Journal of Clinical and Diagnostic Research 2016;10(3):WC06-WC08. 
[10] Sheethal MP, Shashikumar BM. A cross-sectional study on the dermatological conditions among the elderly population in Mandya city. International Journal of Medical Science and Public Health 2015;4(4):467-70.

[11] Doller H. Dermatologic findings in random sample of old persons. Geriatrics 1955;10:421.

[12] Tindall JP, Smith JG. Skin lesions of the aged and their association with internal changes. JAMA 1963;186(12):1039-42.

[13] Verbov J. Skin problems in the older patients. Practitioner 1975;215(1289):612-22.

[14] Weismann K, Krakauer R, Wanscher B. Prevalence of skin diseases in old age. Acta Derm Venereol 1980;60(4):352-3.

[15] Beauregard S, Gilchrest BA. A survey of skin problems and skin care regimens in elderly. Arch Dermatology 1987;123(12):1638-43.
[16] Patange VS, Fernandez RJ. A study of geriatric dermatoses. Indian J Dermatology Venerol Leprol 1995;61(4):206-8.

[17] Durai PC, Thappa DM, Kumari R, et al. Aging in elderly: chronological versus photoaging. Ind J Dermatol 2012;57(5):343-52.

[18] Shashikant DB, Khyalappa R. Study of cutaneous manifestations in geriatrics. International Journal of Research in Medical Sciences 2016;4(5):1343-6.

[19] Grover S, Narsimhalu CRV. A clinical study of skin changes in geriatric age population. Indian $\mathrm{J}$ of Dermatol Venereol and Leprol 2009;75(3):305-6.

[20] Copra A, Kullar J, Chopra D, et al. Cutaneous physiological and pathological changes in elderly. Indian $J$ of Dermatol Venerol and Leprol 2000;66(5):274.

[21] Johnson MTL. Ageing of United States population. In: Gilchrest BA. edr. Dermatology clinics: the ageing skin. 1986:371-8. 